\title{
Peri-operative fluid management in major colorectal surgery: do we comply with current guidance and what are the implications for our patients?
}

\author{
L Vincent $^{1 *}, \mathrm{H}$ Vollmer $^{1}, \mathrm{~S}$ McDouall ${ }^{2}$ \\ From ESICM LIVES 2015 \\ Berlin, Germany. 3-7 October 2015
}

\section{Intr}

Individualised Goal Directed Fluid Therapy, monitoring Cardiac Output, or other surrogates of tissue oxygenation, to guide intra-venous (IV) fluid delivery, is a cornerstone of Enhanced Recovery. Debate surrounds the optimal timing, volume and targets for IV fluid, but the physiological consequences of head-down positioning, pneumoperitoneum (laparoscopic) and the implications of hypoperfusion or oedema for anastomotic integrity, demand scrupulous attention to fluid management in colorectal surgical patients. Flow monitoring devices (eg Oesophageal Doppler) can reduce complications and current guidance stipulates their use [1].

\section{Objectives}

Our objectives were to review local peri-operative fluid management and assess the extent to which Goal Directed Fluid Therapy impacts on outcome in colorectal surgical patients.

- What is compliance with intra-operative Cardiac Output monitoring?

- How does Cardiac Output monitoring influence peri-operative fluid therapy and patient outcome?

\section{Methods}

A retrospective notes analysis was performed on patients who underwent elective major colorectal surgery at the Royal Berkshire Hospital between January and May 2012. Demographics, co-morbidities and intra-operative and postoperative data were recorded, including haemodynamic monitoring, fluid management and post-operative destination. Outcomes recorded included post-operative complications, length of stay and 30-day mortality.

\section{Results}

65 patients were included: mean age 67.6 years; $57 \%$ male.

$5 \%$ operations were open, $77 \%$ laparascopic and $18 \%$ laparoscopic converted to open.

\section{Conclusions}

- Cardiac Output monitoring is not used in a sufficient number of patients.

- Patients with Cardiac Output monitoring received more fluid intra-operatively, had higher complication rates and length of stay. This probably reflects a higher risk cohort, whose complexity is identified early and who are treated aggressively.

- Restriction of intra-operative IV fluid to 1 or 2 litres, made little difference to the total peri-operative intake.

- Post-operative fluid was better restricted in the High Dependency Unit.

To optimise fluid management through the perioperative pathway, we propose:

- Intra-operative Cardiac Output monitoring should be universally implemented in major colorectal surgical patients.

- Patients should be nursed post-operatively in high dependency areas, which are equipped and staffed to facilitate tight, focused, individualised fluid management. 

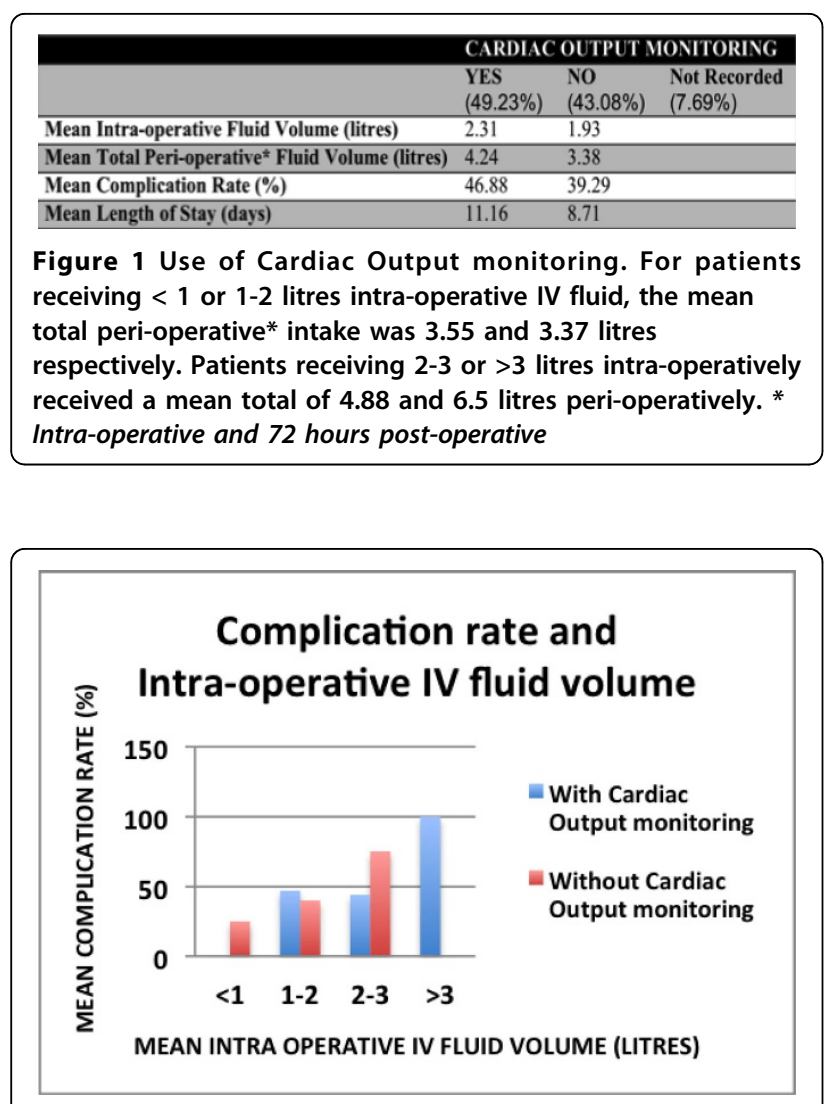

Figure 2 Complication rate and Intra-operative IV fluid.

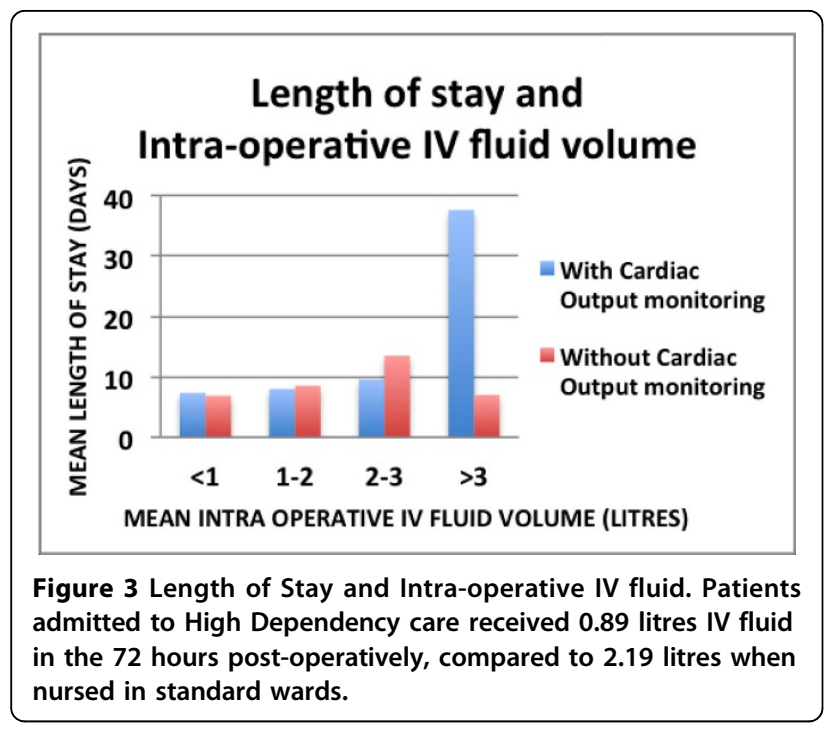

\section{Authors' details}

'Oxford University Hospitals, Anaesthetics, Oxford, United Kingdom. ${ }^{2}$ Royal Berkshire Hospital, Reading, United Kingdom.

Published: 1 October 2015
Reference

1. Gustafsson UO, et al: World J Surg 2013, 37:259-284.

doi:10.1186/2197-425X-3-S1-A236

Cite this article as: Vincent et al.: Peri-operative fluid management in

major colorectal surgery: do we comply with current guidance and

what are the implications for our patients? Intensive Care Medicine

Experimental 2015 3(Suppl 1):A236.

\section{Submit your manuscript to a SpringerOpen ${ }^{\mathcal{O}}$ journal and benefit from:}

- Convenient online submission

- Rigorous peer review

- Immediate publication on acceptance

- Open access: articles freely available online

- High visibility within the field

- Retaining the copyright to your article

Submit your next manuscript at $>$ springeropen.com 